\title{
Watersheds are not static: Implications of climate variability and hydrologic dynamics in modeling
}

\author{
Las cuencas no son estacionarias: implicancias de la variabilidad climática \\ y dinámicas hidrológicas en la modelación
}

\author{
Enrique Muñoz ${ }^{\text {a*}}$, José Luis Arumí ${ }^{\text {b }}$, Diego Rivera ${ }^{\text {b }}$ \\ *Corresponding author: a Universidad Católica de la Santísima Concepción, Facultad de Ingeniería, Concepción, Chile, \\ tel.: 56-41-2345355, emunozo@ucsc.cl \\ b Universidad de Concepción, Facultad de Ingeniería Agrícola, Chillán, Chile.
}

\begin{abstract}
SUMMARY
Demands on the world's freshwater continue to grow as the global population increases, demanding more efficiency in water resources planning and management. Therefore, better confidence and accurate hydrological predictions are needed. Traditionally, many (even most) data-driven hydrological models and hydraulic designs have considered the hydrological behavior of a basin as steady, representing the basin and its hydro-climatic relationships as stable and as long term time-invariant. But currently, a new approach based on hydrologic dynamics where watershed response changes, caused by changes in natural and anthropogenic forcings, are viewed as more adequate and representative of the real hydrological system. This paper discusses the implications of these approaches for modeling and process representation. Finally it is suggested that incorporating the influence of climate change and natural variability into hydrology must be viewed as a priority for water resource planners.
\end{abstract}

Key words: uncertainty, hydrological stationarity, hydrological dynamics, hydrological modeling.

\section{RESUMEN}

La demanda de agua dulce del mundo sigue creciendo a medida que aumenta la población mundial, exigiendo una mayor eficiencia en la planificación y gestión de los recursos hídricos. Por lo tanto, mayor confiabilidad y predicciones hidrológicas precisas resultan necesarias. Tradicionalmente, muchos (sino la mayoría) de los modelos hidrológicos y diseños hidráulicos han considerado el comportamiento hidrológico de una cuenca como estacionario, representando la cuenca y sus relaciones hidro-climáticas como estacionarias e invariantes en el tiempo. Pero en la actualidad, un nuevo enfoque basado en las dinámicas hidrológicas, donde cambios en las respuestas de una cuenca son causados por cambios en los forzantes naturales y antropogénicos, es visto como el más adecuado y representativo de un sistema hidrológico real. En este trabajo se analizan las implicaciones de estos enfoques en el modelado y representación de los procesos hidrológicos. Por último, se propone que incorporar la influencia del cambio climático y de la variabilidad climática natural en la hidrología deba ser considerado como una prioridad para los gestores de recursos hídricos.

Palabras clave: incertidumbre, estacionalidad hidrológica, dinámicas hidrológicas, modelación hidrológica.

\section{INTRODUCTION}

Human demands on the world's available freshwater continue to grow as the global population increases, demanding more efficiency in water resources planning and management. Therefore, holistic tools and better confidence and accurate hydrological predictions are needed. Currently, there are many tools, such as data-driven models, to support water resources planning and management. Tools such as conceptual hydrological models have been widely accepted by the hydrological community (Jin et al. 2010, Muñoz et al. 2011), helping in studies like the understanding of hydrological processes (Fleckenstein et al. 2010), water resources availability (Stone et al. 2010, Piao et al. 2010), climate change impact (Merz et al. 2011), land-use change assessments (Liu and Tong 2011), prediction in un- gauged basins (Samaniego et al. 2010, Wagener and Montanari 2011) and prediction in ungauged climates (Merz et al. 2011, Li et al. 2012). But the traditional idea of hydrological modeling consisting of stable climate and catchment conditions (i.e. a 'stationary world') is falling out of use in favor of incorporating climatic and hydrologic dynamics, i.e. how watershed responses change due to changes in natural and anthropogenic forcings. Therefore, disciplines related to water resources management such as forestry, agriculture and hydroelectricity must begin to incorporate these dynamics into their planning and management.

Hydro-climatic dynamics (or shifts) have largely occurred due to natural conditions (e.g. the reduction in rainfall over southwestern Western Australia during the late 1960s (Baines and Folland 2007), or the exhibited El Niño frequency and amplitude changes before and after the 
late 1970s (Yeh et al. 2009), due to anthropogenic causes such as the greenhouse effect (Pielke 2005, Kundzewics et al. 2008), catchment modifications through river regulation, diversion, extractions, vegetation changes (Peel et al. 2010), or due to land use change (Pielke 2005), among other causes. However, models used in hydrological research and water management frequently assume a 'stationary world' (Peel and Blöschl 2011) where the simulated processes (i.e. the model) are stationary even when the forcings, in some cases, are not considered as stationary. For example, the hydraulic works design is based on statistical hydrological analyses which commonly (if not always) assume that data can be modeled by a single probability distribution function with temporally fixed parameters (mean, variance, and skewness, among many others). Additionally, this stationary world rationale considers that the response of a watershed to changes in forcings is caused by differences in timing and magnitudes of the response, without considering potential changes within-watershed processes such as the water storage in soil or in fractured rocks.

Due to a combination of natural and anthropogenic causes, many authors (e.g. Milly et al. 2008, Wagener et al. 2010, Merz et al. 2011, Coron et al. 2012, Steinschneider et al. 2012) are already establishing that climatic and hydrologic stationarity no longer serves as the default assumption for water and climatic predictions, and therefore water management, planning and the design of infrastructures should not be based on 'stationary world model' results.

As stated by Wagener et al. (2010), 'hydrology requires a paradigm shift in which predictions of system behavior that are beyond the range of previously observed variability become the new norm. To achieve this shift, hydrologists must become both synthesists, observing and analyzing the system as a holistic entity, and analysts, understanding the functioning of individual system components (hydrological processes such as surface, sub-surface and groundwater runoff and storage, infiltration, exfiltration and evapotranspiration, among others), while operating firmly within a well-designed hypothesis-testing framework (Blöschl 2006). This is the basis of the hydrologic dynamics concept, where a basin's processes and hydro-climatic relationships are viewed as time-variant. In this paper, a discussion of the stationary and dynamic hydrological modeling approach, based on model uncertainties and model predictability, is carried out. Moreover, it is suggested that incorporating the influence of climate change and natural variability into modeling must be viewed as a priority for water resource planners.

\section{MODEL UNCERTAINTY}

The modeling process has usually been beset by uncertainties in: i) the input data used to drive the model (Donohue et al. 2010), ii) the output data used for calibration (e.g. streamflow) (McMillan et al. 2010), iii) the calibration method and performance measurements adopted (ob- jective functions) (Efstratiadis and Koutsoyiannins 2010), and/or iv) the model structure (Andréassian et al. 2009), contributing to model and parameter uncertainty. Therefore, adequate hydrological modeling is necessary to understand and simulate the dominant processes and dynamics that control the hydric balance in a basin, reduce model uncertainty, improve the output and prediction confidence degree, and predict in a realistic manner the future behavior of a basin under changing conditions (Merz et al. 2011).

In earth sciences and especially in hydrology, there is a great need to adequately choose and perform conceptual models, reduce their predictive uncertainty, and improve the understanding of hydrological processes, by improving the model structure, ensuring the identifiability of the parameters and/or reducing or limiting the non-uniqueness (equifinality) of model parameters. Only by attempting to resolve the above mentioned issues will the model predictions and related hydraulic designs be better prepared for the real world system. Additionally, model performance relies on measured data, which is also subject to uncertainties (sampling frequencies, sampling locations, representativeness of variables), considering that measured variables are surrogates of hydrological processes. Thus, improving monitoring networks will also contribute to improving hydrological knowledge.

In a conceptual model it is known that different sets of parameters are often distributed within a viable range, and that sometimes, even different conceptualizations of the system (model structure) can give equally good results in terms of predefined objective functions (Wagener et al. 2003). This behavior relative to the parameters of a model is defined as equifinality (Beven 2006). The thesis of equifinality aims at highlighting that there are various reasonable (or realistic) representations of a basin that cannot be easily rejected, and therefore must be considered in the estimation of uncertainty associated with the predictions. Put in another way, there are varied parameterizations of a model that can lead to similar statistical results, and therefore just one set of correct parameters (a 'stationary model') cannot be selected (Beven 2006), mainly due to the different response modes of a basin that are not simulated in a 'stationary model'.

\section{STATIONARITY OR DYNAMIC HYDROLOGIC MODELING}

Hydrological modeling must be viewed as a tool for water management, planning and analysis. Models are virtual hydrological laboratories where both specific studies and conceptual generalizations are developed to explore and test hypotheses (Kirchner 2006) providing a basis to understand and investigate relationships between climate and water resources (Choia and Deal 2008).

Systems for management of water throughout the developed world have been designed and operated under the assumption of stationarity, where runoff processes are 
modeled as time-invariant. The idea that natural systems fluctuate within an unchanging envelope of variability is a foundational concept that permeates training and practice in water-resource engineering. It implies that any variable (e.g., annual streamflow or annual flood peak) has a timeinvariant behavior (Milly et al. 2008); however, hydro-climatic dynamics have occurred, largely due to a combination of i) seasonality, ii) variability (caused for example by phenomena such as El Niño Southern Oscillation (ENSO) and Interdecadal Pacific Oscillation (Quintana and Aceituno 2012)), and iii) natural and anthropogenic hydro-climatic change (e.g. Kundzewics et al. 2008, Yeh et al. 2009). A simplistic approach widely used in modeling assumes that model parameters are time-invariant and any variability is absorbed by the input-data, such as the way in which the impact of climate change on hydrological systems has been traditionally estimated (e.g. Stehr et al. 2010, Espinosa et al. 2011). However, how models and model parameters must change with time is currently not very well understood, and has become a major challenge in hydrology (Wagener et al. 2010, Montanari et al. 2010, Coron et al. 2012).

Currently, a new trend aimed at reducing predictive uncertainty and simulating hydrological process dynamics is gaining strength in modeling (Steinschneider et al. 2012). Authors like Merz et al. (2011), Singh et al. (2011) and Li et al. (2012) have shown real cases where hydrologic dynamics were observed, identifying parameters and hydro-climatic changes. Therefore, hydro-climatic dynamics in modeling --aiming at simulating hydrological processes in a realistic manner, thus simulating and understanding their dynamics-- must be viewed as a priority in order to reduce model predictive uncertainty and improve the confidence degree of model outputs.

\section{DISCUSSION}

Nowadays there are many studies published in scientific literature where the 'stationary world' has been an underlying assumption. The problem is that in climate change impact studies or in long-term hydrological simulations, the hydrological predictions or estimated impacts can be even more uncertain than the average hydrological behavior of a basin. As stated, if climate conditions change, there are several reasons that hydrological behavior may change as well. For example if average winter air temperature increases and the elevation of the snow-rain line becomes higher, less snow will be stored in the Andes Mountains. However, the same change in temperature will avoid soil freezing, and therefore the rate of infiltrated rainfall will increase, recharging the central valley aquifer (a recently understood process of mountain front recharge described by Carling et al. 2012).

The use of stationary conditions produces an oversimplification of the conceptualization of hydrological processes. Thus, water availability (watershed storage) is very often only related to rainfall which can be simulated as dy- namic, but without considering changes or dynamics in the hydrological compartments. However, following the previous example, changes in the snow-rain line would pose a challenge in assessing changes in the different storages of the watershed, calling for integrated rainfall, snowfall, groundwater, and soil measurements and modeling.

A good understanding of hydrological processes in a watershed will allow stakeholders to make better water management decisions, reducing the uncertainties associated with the different driving forces that can affect the watershed. Through the use of uncertainty analysis in hydrological modeling, the analysis of the appropriate model structure, identifiability of model parameters, as well as reliable and representative measured data, it is possible to learn about the dominant hydrological processes in the watershed and how those processes change along the different cycles of climate variability and change that are historically recorded and used in modeling. For example, the use of the hydrologic dynamic concept allows the understanding of soil behavior and its effect on direct runoff and soil water storage (Muñoz 2011). In the case of an Andean watershed it was possible to identify the importance of groundwater transfer among sub-basins of the Itata basin, which is the case of the Diguillín River (Zúñiga et al. 2012). Moreover, the understanding of hydrological dynamics also has implications at the local scale as the entrance of potential contaminants to different compartments of the system depends on regional processes.

\section{CONCLUSIONS}

The improvement of the knowledge of hydrological processes, through the consideration of hydrologic dynamics, the incorporation of the influence of climate variability into water resources planning and management, and the use of historical data to correctly assess the effect of climate and land use change scenarios must be viewed as a priority in hydrological sciences. In such a way, the critical issues of the hydrological system can be understood. Variability is part of the very nature of hydrological systems; we must live with this reality, not try to hide it, by introducing new hydrological concepts in research, teaching, communications, planning and practice.

\section{ACKNOWLEDGEMENTS}

The authors thank FONDECYT 11121287 "Hydrological process dynamics in Andean basins. Identifying the driving forces, and implications in model predictability and climate change impact studies", FONDECYT 1110298, "Water availability in a stressed Andean watershed in Central Chile: Vulnerability under climate variability”, and FONDECYT 11090032, "Water and solutes fluxes below irrigated fields: a numerical approach supported by field research to assess the interaction between irrigation and groundwater systems”. 


\section{REFERENCES}

Andréassian V, C Perrin, N Le Moine, J Lerat, C Loumagne, L Oudin, M Mathevet, H Ramos, A Valéry. 2009. HESS Opinions "Crash tests for a standardized evaluation of hydrological models”. Hydrology and Earth System Sciences 13: 1757-1764.

Baines P, C Folland. 2007. Evidence for a rapid global climate shi$\mathrm{ft}$ across the late 1960s. Journal of Climate 20: 2721-2744.

Beven K. 2006. A manifesto for the equifinality thesis. Journal of Hydrology 320(1- 2): 18- 36.

Blöschl G. 2006. Hydrologic synthesis: Across process, places, and scales. Water Resources Research 42: 1-3.

Carling G, A Mayo, D Tingey, J Bruthans. 2012. Mechanisms, timing, and rates of arid region mountain front recharge. Journal of Hydrology 428-429: 15-31.

Choia W, M Deal. 2008. Assessing hydrological impact of potential land use change through hydrological and land use change modeling for the Kishwaukee River basin (USA). Journal of Environmental Management 88: 1119-1130.

Coron L, V Andréassian, C Perrin, J Lerat, J Vaze, M Bourqui, F Hendrickx. 2012. Crash testing hydrological models in contrasted climate conditions: An experiment on 216 Australian catchments. Water Resources Research 48: W05552.

Donohue R, T McVicar, M Roderick. 2010. Assessing the ability of potential evaporation formulations to capture the dynamics in evaporative demand within a changing climate. Journal of Hydrology 386: 186-197.

Efstratiadis A, D Koutsoyiannis. 2010. One decade of multi-objective calibration approaches in hydrological modelling: A review. Hydrological Sciences Journal 55(1): 58-78.

Espinosa J, H Uribe, J Arumí, D Rivera, A Stehr. 2011. Vulnerabilidad del recurso hídrico respecto a actividades agrícolas en diferentes subcuencas del rio Limarí. Gestión Ambiental 22:15-30.

Fleckenstein JH, S Krause, DM Hannah, F Boano. 2010. Groundwater-surface water interactions: new methods and models to improve understanding of processes and dynamics. Advances in Water Resources 33: 1291-1295.

Jin X, C-Y Xu, Q Zhang, VP Singh. 2010. Parameter and modeling uncertainty simulated by GLUE and a formal Bayesian method for a conceptual hydrological model. Journal of Hydrology 383: 147-155.

Kirchner J. 2006. Getting the right answers for the right reasons: Linking measurements analyses and models to advance the science of hydrology. Water Resources Research 42: 1-5.

Kundzewics Z, L Mata, N Arnell, P Döll, B Jimenez, K Miller, T Oki, Z Sen, I Shiklomanov. 2008. The implications of projected climate change for freshwater resources and their management. Hydrological Sciences Journal 53(1): 3-10.

Li C, L Zhang, H Wang, Y Zhang, F Yu, D Yan. 2012. The transferability of hydrological models under nonstationary climatic conditions. Hydrology and Earth System Sciences 16: 1239-1254.

Liu Z, STY Tong. 2011. Using HSPF to Model the Hydrologic and Water Quality Impacts of Riparian Land-Use Change in a Small Watershed. Journal of Environmental Informatics 17(1): 1-14.

McMillan H, J Freer, F Pappenberger, T Krueger, M Clark. 2010. Impacts of uncertain river flow data on rainfall-runoff model calibration and discharge predictions. Hydrological
Processes 24: 1270-1284.

Merz R, J Parajka, G Blöschl. 2011. Time stability of catchment model parameters: Implications for climate impact analyses. Water Resources Research 47: 1-17.

Milly P, J Betancourt, M Falkenmark, R Hirsch, Z Kundzewicz, D Lettenmaier, R Stouffer. 2008. Stationarity is dead: Whither water management? Science 319: 573-574.

Montanari A, G Blöschl, M Sivapalan, H Savenije. 2010. Getting on target. Public Service Review: UK Science and Technology 7:167-169.

Muñoz E. 2011. Perfeccionamiento de un modelo hidrológico: aplicación de análisis de identificabilidad dinámico y uso de datos grillados. Tesis doctoral, Chillán, Chile. Departamento de Recursos Hídricos, Universidad de Concepción, Chile. 100 p.

Muñoz E, C Álvarez, M Billib, JL Arumí, D Rivera. 2011. Comparison of gridded and measured rainfall data for basin scale hydrological studies. Chilean Journal of Agricultural Research 71(3): 459-468.

Peel M, G Blöschl. 2011. Hydrological modelling in a changing world. Progress in Physical Geography 35(2): 249-261.

Peel M, T McMahon, B Finlayson. 2010. Vegetation impact on mean annual evapotranspiration at a global catchment scale. Water Resources Research 46: 1-16.

Piao S, P Ciais, Y Huang, Z Shen, S Peng, J Li, L Zhou, H Liu, Y Ma, Y Ding, P Friedlingstein, C Liu, Kun Tan, Y Yu, T Zhang, J Fang. 2010. Nature 467: 43-51.

Pielke R. 2005. Land Use and Climate Change. Atmospheric Science 310: 1625-1626.

Quintana J, P Aceituno. 2012. Changes in the rainfall regime along the extratropical west coast of South America (Chile): 30-43 S. Atmósfera 25(1): 1-22.

Samaniego L, A Bárdossy, R Kumar. 2010. Streamflow prediction in ungauged catchments using copula-based dissimilarity measures. Water Resources Research 46: 1-22.

Singh R, T Wagener, K vanWerkhoven, M Mann, R Crane. 2011. A trading-space-for-time approach to probabilistic continuous streamflow predictions in a changing climate - accounting for changing watershed behavior. Hydrology and Earth System Sciences 15: 3591-3603.

Stehr A, P Debels, JL Arumí, H Alcayaga, F Romero. 2010. Modelación de la respuesta hidrológica al cambio climático: experiencias de dos cuencas de la zona centro-sur de Chile. Tecnología y Ciencias del Agua 4(1): 37-58.

Steinschneider S, A Polebitski, C Brown, BH Letcher. 2012. Toward a statistical framework to quantify the uncertainties of hydrologic response under climate change. Water Resources Research 48: W11525.

Stone KC, PG Hunt, KB Cantrell, KS Ro. 2010. The potential impacts of biomass feedstock production on water resource availability. Bioresource Technology 101(6): 2014-2025.

Wagener T, A Montanari. 2011. Convergence of approaches toward reducing uncertainty in predictions in ungauged basins. Water Resources Research 47: 1-8.

Wagener T, N McIntyre, M Lees, H Wheater. H Gupta. 2003. Towards reduced uncertainty in conceptual rainfall-runoff modeling: dynamic identifiability analysis. Hydrological Processes 17(2): 455-476.

Wagener T, M Sivapalan, P Troch, B McGlynn, C Harman, H Gupta, P Kumar, P Rao, N Basu, J Wilson. 2010. The future of hydrology: An evolving science for a changing world. 
Water Resources Research 46: 1-10.

Yeh S-W, J-S Kug, B Dewitte, M-H Kwon, B Kirtman, F-F Jin. 2009. El Niño in a changing climate. Nature 461: 511-511.

Zúñiga R. 2012. Interacción agua superficial-subterránea en una cuenca andina de Chile centro-sur. Vulnerabilidad ante escenarios de variabilidad climática. Tesis Ingeniería Civil. Concepción, Chile. Facultad de Ingeniería, Universidad Católica de la Santísima Concepción. 178 p.

Recibido: 20.08.12

Aceptado: 28.12 .12 
